\title{
Apps as a learning vehicle in urban naturing and sports fields
}

DOI: $10.46932 / \mathrm{sfjdv2n1-032}$

Received in: November 1st, 2020

Accepted in: December 30th, 2020

\section{Alicia Perdigones}

Dra. Ingeniera Agrónoma. Departamento de Ingeniería Agroforestal Universidad Politécnica de Madrid, Ciudad Universitaria, 28040 Madrid

\section{Fernando Ruiz-Mazarrón}

Dr. Ingeniero Agrónomo. Departamento de Ingeniería Agroforestal Universidad Politécnica de Madrid, Ciudad Universitaria, 28040 Madrid

\section{Ignacio Cañas}

Dr. Ingeniero Agrónomo. Departamento de Ingeniería Agroforestal Universidad Politécnica de Madrid, Ciudad Universitaria, 28040 Madrid

\section{José Luis García}

Dr. Ingeniero Agrónomo. Departamento de Ingeniería Agroforestal Universidad Politécnica de Madrid

Ciudad Universitaria, 28040 Madrid

\begin{abstract}
Electronic devices represent an opportunity for the teaching-learning process in the classroom, especially at the present time, where in many university centers, due to health security, teaching has become online. The use of apps (applications) or what is the same, applications for mobile devices such as tablets or smartphones, is increasing in the private sphere, there are applications for the calculation of distances and speeds traveled, or geolocation. There are also interesting applications to be used at the University through the practices of subjects oriented towards engineering and the professional environment. Examples could be applications that allow you to work with devices as if they were an accelerometer, surface calculators, or apps that allow you to detect diseases in plants or irrigation needs. Determining the electronic support most used by students in the classroom will allow to know the possibilities of incorporating these applications in the university environment to face-to-face teaching.
\end{abstract}

Keywords: ICTs, apps, engineering, mobile phones.

\section{INTRODUCTION}

The methodologies used in the teaching and learning process of face-to-face teaching have been adapted to the rapid evolution of technology at all times. What were initially slate-supported master classes have evolved progressively, moving to master classes supported by transparencies and subsequently supported by Power Point presentations, incorporating videos and access to web pages, 
making the classes more dynamic; the evolution has been such in the last decade, that in some cases, there is already work in the classroom with augmented reality.

In addition to the incorporation of technology into classrooms, the methodology of master classes has been partially or totally displaced by collaborative systems, in which student participation is essential. This has given way to project-based learning, gaming-based learning (gamification) (CorchueloRodríguez, 2018; González, et al., 2021), in challenges, in augmented reality (Badilla \& Sandoval, 2015), or learning-service (learning through collaboration with activities that provide service to society) (Gutiérrez-Sánchez \& Moreno, 2018; Álvarez-Muñoz et al., 2020), among others. Practical laboratory or field classes also take on importance in this new educational framework, trying to bring the practice of teaching closer to the way of working in private enterprise. The use of computer technology and applications, essential in the industrial and business environment, must take on importance in the academic environment, regardless of the area of knowledge. Khamis \& Azam (2019), introduce an "ergonomics risk assessment (ERA) apps", which brings students closer to solving their own engineering problems, as would be done in the professional field, also favoring the development of transverse skills, such as communication. Meanwhile, Rivera, Banavar \& Barry (2018), developed app-based laboratory practices for the improvement of science and engineering teaching; with this methodology, they also managed to increase their students' motivation in the areas of technological knowledge (STEM, Science, Technology, Engineering and Mathematics).

Computer-assisted applications are already commonplace in engineering teaching, such as those for the calculation of structures (Metal 3D), design of electrical installations (Dialux, Prysmitool), statistical calculations (Statgraphics), 3D simulation and modelling (Matlab, SketchUp), calculation of phytosanitary application doses (DOSACITRIC), among many others. The use of these computer applications facilitates the learning of the subject (Temporao \& Pavani, 2020). Buna, Tafone \& Hohxa (2018) document in their article an experience in Physical Engineering, in which they use modelling software to recreate examples typical of physics, such as heat transfer, thermoelectric or acoustic effects. This software has allowed students to improve their understanding of physics and successfully incorporate this software as an educational medium in this degree.

We need to go further and use new technologies to improve practical training, and there are many possibilities at present. The mobile phones currently on the market are capable of supporting applications that are used naturally by millions of people in the private sphere; Whatsapp, Google Maps or Nike + running are some of these applications that are used as a means of communication, route location or training plan, respectively. These applications could be used not only in the private sphere, but as very interesting tools for university teaching. 
It is possible, for example, to use free apps (applications for mobile devices) for plant species identification, irrigation calculation, maintenance of gardens and sports fields, area calculation, speed calculation, applications for geolocation, among many others. However, they cannot be used without prior knowledge of the mobile devices with which students attend class, to see their actual application capacity.

Based on an educational innovation project funded by the Universidad Politécnica of Madrid, entitled "Social networks and use of ICTs as a learning vehicle in green areas and urban naturing" (20192020), a study of apps oriented to the subjects of the area of Agroforestry Engineering has been carried out, with an additional study to know, through surveys prepared for students, what type of mobile devices students have in classes.

Although the study focuses on the areas of urban naturing and sports fields, the surveys are being carried out on all bachelor's degrees taught at the Superior Technical College of Agronomic, Nutritional and Bio-systems Engineering (ETSIAAB) of the Universidad Politécnica of Madrid: Degree in Agricultural Engineering, Degree in Agro-Environmental Engineering, Degree in Food Engineering, Degree in Agricultural Sciences and Bio-economics and Degree in Biotechnology.

Urban nature is a current issue, linked to the environment, with which it is intended to green cities by improving the microclimate, urban landscaping and favoring, in some cases, social aspects of the neighbors. Due to its transversality and timeliness, it is an area where the use of apps is possible either for the design of the facilities or for their maintenance.

\section{MATERIALS AND METHODS}

This article corresponds to a study carried out within the educational innovation project "Social networks and the use of ICTs as a vehicle for learning in green areas and urban nature", funded by the Universidad Politécnica of Madrid. The objective was to locate apps with possibilities for use in the practical classes of Agricultural Engineering. The search was carried out through the Play Store and App Store; The topics sought are related to the design and maintenance of green areas, and urban naturing.

Prior to the search for apps, it was studied whether students had the possibility of bringing electronic devices into the classroom and what characteristics they had. To this end, a survey was conducted through the institutional email, to all students enrolled in ETSIAAB; it should be mentioned that it is an Engineering School of a Public University. The survey was divided into two parts; a first part, in relation to the personal data of the students (age, sex, degree they study, characteristics of the school in which they studied, etc.) and a second part relating to the electronic devices available at home, their operating system, number of cohabitants, and their use of apps. 
Within the mobile operating systems (oriented towards wireless connectivity) for which the apps are developed, we find the following:

- Android: mobile operating system developed by Android Inc., a Google company since 2005, and designed for mobile devices with touch screen (phones, tablets).

- iOS: Mobile operating system developed by Apple Inc. Used on devices such as iPod touch and iPad. It is not possible to install it on devices of other companies.

- Windows 10 mobile - Windows Phone: mobile operating system developed by Microsoft, available since 2015 for all types of platforms (smartphones, tablets, computers).

- BlackBerry OS: A mobile operating system developed by BlackBerry for their devices.

- Symbian: mobile operating system that is born as an alliance between companies such as Nokia, Sony Ericsson, Samsung, LG, or Motorola, among others.

- Firefox OS: mobile operating system developed by Mozilla Corporation, for smartphones and tablets.

- Ubuntu Touch: Linux based mobile operating system, marketed since 2013.

The mobile devices on which mobile apps can be installed are:

- Smartphone: laptop, small with the properties of a mobile phone, but with greater capacity to store data, perform activities, include email and with greater connectivity (WIFI internet access), multimedia function (camera and video, video/mp3 player), diary, contact manager, accelerometers, GPS (global positioning system), and navigation programs. There are different ranges, depending on the company that develops it; iPhone, for example, is a Smartphone developed by Apple Inc., with $i O S$ operating system.

- iPad: Tablet type electronic device developed by Apple Inc., in 2012, with iOS operating system. By design it is somewhere between what corresponds to a smartphone and a laptop. Due to its size, it favors reading documents.

- Tablet: type of laptop integrated into a touch screen, with which you interact without the need for a physical keyboard. They usually integrate a microprocessor, touch screen, speaker and microphone, video camera, camera, Radio, GPS (Global Positioning System), wireless connections (WIFI, bluetooth, etc.). 


\section{RESULTS AND DISCUSSION}

A total of 73 surveys were collected (41.1\% male; $48.9 \%$ female), through which it has been possible to know which devices, and characteristics, students have in class. $97.3 \%$ of students say they can take a mobile phone to class; $90.4 \%$ say they could carry a laptop and only $43.8 \%$ say they could carry a digital tablet. The most used operating system is Android (75.3\%), compared to iOS (21.9\%) and others $(2.8 \%)$. It is therefore possible to think about performing classroom practices and activities using mobile phones and applications that can be implemented on Android and iOS operating systems.

In general, students do not use professional apps in the subjects; only $15.3 \%$ claim to use some app in the classroom (Google, Dialux, PlantNet, among others). However, they all claim to use apps for their personal lives. Among the apps they use most are applications for communication, such as Whatsapp $(97.3 \%)$, related to geolocation $(87.7 \%)$, related to means of transport $(79.5 \%)$, related to training $(71.2 \%)$, related to catering and leisure (32.9\%), related to sport $(30.1 \%)$ and related to some trade $(20.5 \%)$. Only $1.4 \%$ claim not to use any apps in their day to day lives (Figure 1).

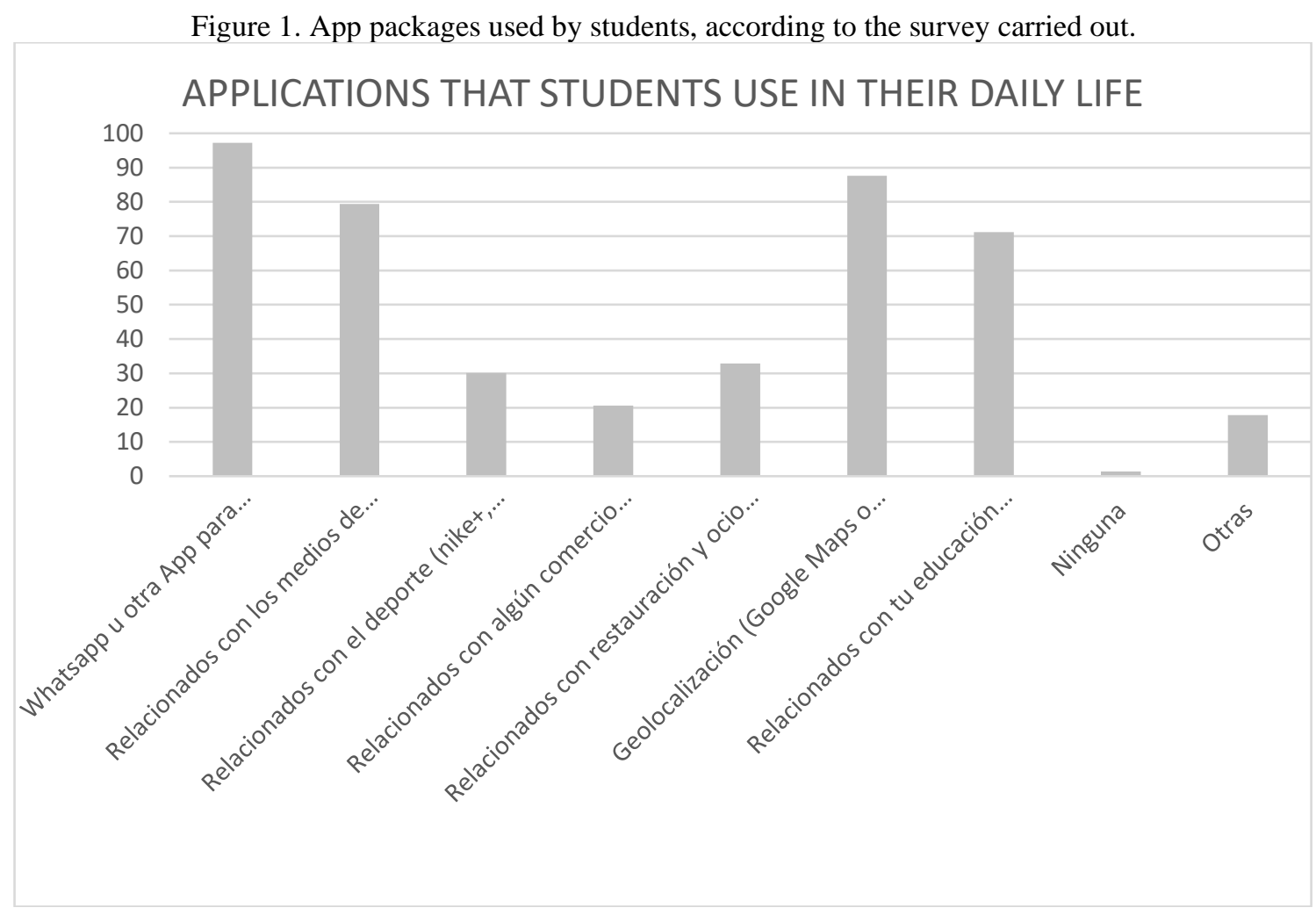

There are general applications, used in the personal environment of students, that could be used in class, such as geolocation systems, or sports-related apps, being able to measure distances, speeds, tours, etc. These could be useful, for example, in subjects such as agricultural machinery, machinery for gardening and sports fields, topology or physics. 
Table 1. General apps for determining technical parameters.

\begin{tabular}{|c|c|c|c|c|c|c|}
\hline Implementation & General Use & Owner & Operating system & $\begin{array}{l}\text { Size } \\
\text { (MB) }\end{array}$ & Parameters & \\
\hline Runtastic & Personal training & Adidas & $\begin{array}{l}\text { iOS, Android, } \\
\text { Windows Phone and } \\
\text { Blackberry }\end{array}$ & 50.76 & $\begin{array}{l}\text { Maximum } \\
\text { Minimum } \\
\text { Average } \\
\text { Distances, } \\
\text { Performed, } \\
\text { Gap }\end{array}$ & $\begin{array}{r}\text { Speed, } \\
\text { Speed, } \\
\text { Speed, } \\
\text { Travel } \\
\text { Elevation }\end{array}$ \\
\hline Nike Run Club & Personal training & Nike Inc. & $\begin{array}{l}\text { iOS 11.0, } \\
\text { Android }\end{array}$ & $\begin{array}{l}235.5 \\
68.8\end{array}$ & $\begin{array}{l}\text { Maximum } \\
\text { Minimum } \\
\text { Average } \\
\text { Distances, } \\
\text { Performed, } \\
\text { Gap }\end{array}$ & $\begin{array}{r}\text { Speed, } \\
\text { Speed, } \\
\text { Speed, } \\
\text { Travel } \\
\text { Elevation }\end{array}$ \\
\hline $\begin{array}{l}\text { Measuring areas } \\
\text { and distances }\end{array}$ & $\begin{array}{l}\text { Measurement of } \\
\text { areas and } \\
\text { distances on the } \\
\text { ground }\end{array}$ & Farmis & Android 4.2 & 23 & $\begin{array}{l}\text { Areas, } \\
\text { distances }\end{array}$ & perimeter, \\
\hline $\begin{array}{l}\text { GPS Digital } \\
\text { Speed Tracker }\end{array}$ & $\begin{array}{l}\text { Speed } \\
\text { measurement }\end{array}$ & Joao Silveira & iOS 9.0 & & $\begin{array}{l}\text { Current } \\
\text { maximum } \\
\text { average } \\
\text { distance, alti }\end{array}$ & $\begin{array}{l}\text { speed, } \\
\text { speed, } \\
\text { speed, } \\
\text { titude }\end{array}$ \\
\hline
\end{tabular}

Professionally and through apps with technical content, there are applications to calibrate phytosanitary application equipment, determine plant species, identify diseases and pests or design gardens, among many others. Table 2 shows some of these apps.

Table 2. Specific apps for use in green areas.

\begin{tabular}{|c|c|c|c|c|c|}
\hline Implementation & Use & Owner/Developer: & $\begin{array}{l}\text { Operating } \\
\text { system* }\end{array}$ & Size (MB) & $\begin{array}{l}\text { Parameters } \\
\text { Estimated }\end{array}$ \\
\hline $\begin{array}{l}\text { Sprayer } \\
\text { calibrator }\end{array}$ & $\begin{array}{l}\text { Calibration for } \\
\text { plant protection } \\
\text { products }\end{array}$ & Farmis & Android 4.1 & 5.4 & $\begin{array}{l}\text { Tractor speed and } \\
\text { pressure required }\end{array}$ \\
\hline $\begin{array}{l}\text { Agrio - Smart } \\
\text { farming }\end{array}$ & $\begin{array}{l}\text { Identification } \\
\text { and treatment of } \\
\text { pests and } \\
\text { diseases through } \\
\text { photographs } \\
\text { taken }\end{array}$ & Saillog Ltd & $\begin{array}{l}\text { iOS 11.0, } \\
\text { Android } 4.1\end{array}$ & $\begin{array}{l}33.4 \\
18.88\end{array}$ & $\begin{array}{l}\text { Identification and } \\
\text { treatment of the } \\
\text { disease or pest }\end{array}$ \\
\hline $\begin{array}{l}\text { Plant protection } \\
\text { products }\end{array}$ & $\begin{array}{l}\text { Download plant } \\
\text { protection } \\
\text { product files }\end{array}$ & Ager Technology SL & $\begin{array}{l}\text { iOS 8.0, } \\
\text { Android } 2.2\end{array}$ & $\begin{array}{l}2 \\
184 \mathrm{~kb}\end{array}$ & $\begin{array}{l}\text { Characteristics of } \\
\text { plant protection } \\
\text { products }\end{array}$ \\
\hline
\end{tabular}




\begin{tabular}{|c|c|c|c|c|c|}
\hline Tee2Green Pro & $\begin{array}{l}\text { Assessment of } \\
\text { golf course } \\
\text { maintenance } \\
\text { conditions }\end{array}$ & $\begin{array}{l}\text { Tee2Green } \\
\text { Benchmarking }\end{array}$ & Android 5.0 & 11 & $\begin{array}{l}\text { Quality of tees, } \\
\text { greens, bunkers, } \\
\text { etc. }\end{array}$ \\
\hline ArbolApp & $\begin{array}{l}\text { Tree } \\
\text { identification }\end{array}$ & $\begin{array}{l}\text { Royal Botanical } \\
\text { Garden - CSIC }\end{array}$ & $\begin{array}{l}\text { Android } 4.0 \\
\text { iOS } 9.0\end{array}$ & $\begin{array}{l}63 \\
76.9\end{array}$ & $\begin{array}{l}\text { Identify trees on } \\
\text { the Iberian } \\
\text { Peninsula }\end{array}$ \\
\hline Light Meter & $\begin{array}{l}\text { Measures the } \\
\text { amount of light } \\
\text { on a plane (lx) }\end{array}$ & $\begin{array}{l}\text { Google } \\
\text { Ltd }\end{array}$ & Android 4.0.3. & 4.1 & Lighting (lux) \\
\hline IColor & $\begin{array}{l}\text { Identification of } \\
\text { the wavelength } \\
\text { of a light }\end{array}$ & $\begin{array}{l}\text { Google } \\
\text { Ltd }\end{array}$ & Android 1.0 & $90 \mathrm{~kb}$ & $\begin{array}{l}\text { Wavelength, } \\
\text { frequency }\end{array}$ \\
\hline $\begin{array}{l}\text { PRO Key } \\
\text { Electrical } \\
\text { Calculations }\end{array}$ & $\begin{array}{l}\text { Calculate } \\
\text { lighting } \\
\text { parameters }\end{array}$ & $\begin{array}{l}\text { Egal Net di Ettore } \\
\text { Gallina }\end{array}$ & Android 4.0 & 1.1 & $\begin{array}{l}\text { Light } \\
\text { Lighting, }\end{array}$ \\
\hline
\end{tabular}

*Minimum version of Operating System valid to support the application.

Table 1 and Table 2 include only a few apps as an example among the many localized; on the internet there are many other applications supported by different operating systems, which allow to work in both the educational and professional areas, being very interesting their use in teaching practices.

As an example, the last three applications that appear in table 2 can be used in the area of urban nature to analyze the amount (Light Meter) and type of light (IColor) that a plant surface receives, or to design the lighting to be installed (Electrical calculations PRO key).

\section{CONCLUSIONS}

Mobile applications or apps are tools that can be used for educational purposes at university level, for the practical part of the subjects or in collaborative work. Geolocation systems, for example, allow us to know speeds, distances, critical points, etc., in the gardening area.

In Public University Centers, such as the Universidad Politécnica of Madrid, you can think of using the mobile phone as a means to make use of these apps in the classroom, since practically all students have one. Before implementing the use of apps in the classroom, the type of mobile device that students have in each case, as well as the operating system used, will have to be taken into account.

\section{ACKNOWLEDGMENTS}

This study is included in the project "Social networks and use of ICTs as a vehicle for learning in green areas and urban naturing", funded by the Universidad Politécnica of Madrid. 


\section{REFERENCES}

Álvarez-Muñoz, J.S., Bernárdez-Gómez, A. \& Belmonte, M.L. (2020). Trabajando la educación ambiental desde la metodología aprendizaje-servicio. South Florida Journal of Development, Miami, 2(1), 105-118.

Badilla Quesada, M. \& Sandoval Poveda, A.M. (2015). Realidad aumentada como tecnología aplicada a la educación superior: Una experiencia en desarrollo. Innovaciones educativas, 23, 41-49.

Buna, D., Tafone, D. \& Hohxa, L. (2018). Integration of comsol multiphysics in engineering physics courses. From theory to iphone apps. 11th International Conference Of Education, Research And Innovation (ICERI2018), España, 10171-10174. doi: 10.21125/iceri.2018.0091

Corchuelo-Rodríguez, C.A. (2018). Gamificación en educación superior: Experiencia innovadora para motivar estudiantes y dinamizar contenidos en el aula. (2018). EDUTEC- Revista electrónica de tecnología educativa, 63, 29-41. doi: https://doi.org/10.21556/edutec.2018.63.927

González Muñoz, J., Cánovas Calderón, B., Muñoz Melgar, R. \& Rabal Alonso, J.M. (2021). Importance of the use of interactive methodologies in primary education: gamification. Didactic proposal. South Florida Journal of Development, 2(1), 264-274.

Gutiérrez-Sánchez, M. \& Moreno Abellán, P. (2018). El aprendizaje servicio como metodología para la formación integral de los estudiantes universitarios. EDETANIA, 53, 185-202.

Khamis, N.K. \& Azam, A.M.A. (2019). Learning Aids of Risk Assessment Apps for Practical Engineering Student: A Case Study. International Journal Of Emerging Technologies In Learning, 14(24), 81-95.

Rivera, S., Banavar, M.K. \& Barry, D. (2018). Mobile apps for Incorporating Science and Engineering Practices in K-12 STEM Labs. 2018 IEEE Frontiers In Education Conference (FIE), USA, 1-5, doi: 10.1109/FIE.2018.8659105

Temporao, G.P. \& Pavani, A.M. B. (2020). Tailoring apps and podcasts for mobile learning in engineering education. Talk: 14th International Technology, Education and Development Conference (INTED), Spain, INTED Proceedings, 5203-5208, doi: 10.21125/inted.2020 